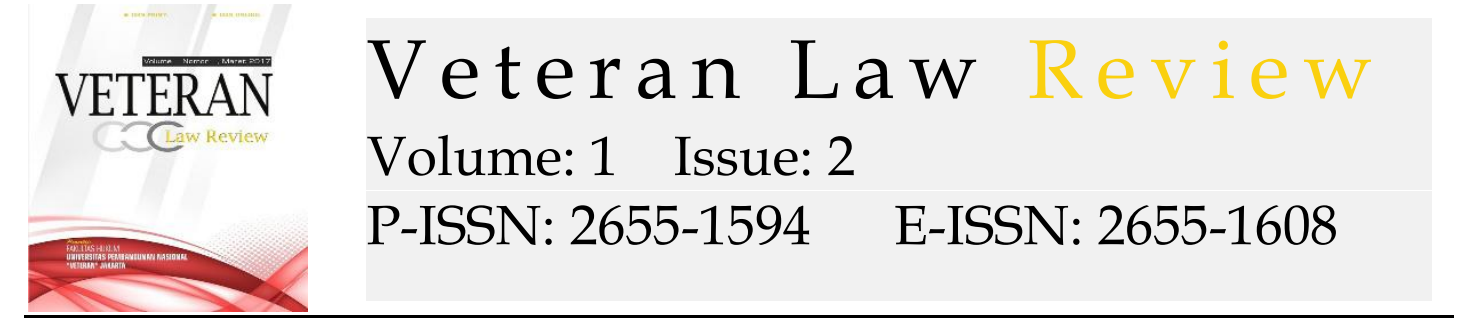

\title{
The Implementation of Economic and Social Council's Duties as a United Nations Organs
}

\author{
Natasya Fila Rais
}

Faculty of Law, Indonesia University, E-mail: natasya.filarais@gmail.com

\begin{tabular}{|c|c|}
\hline ARTICLE INFO & ABSTRACT \\
\hline $\begin{array}{l}\text { How to cite: } \\
\text { Rais, Fila Natasya. } \\
\text { (2019). The } \\
\text { Implementation of } \\
\text { Economic and Social } \\
\text { Council's Duties as a } \\
\text { United Nations organ. } \\
\text { Veteran Law Review. } 2 \\
\text { (1). 1-20 }\end{array}$ & $\begin{array}{l}\text { This article will describe the history of the Economic and Social } \\
\text { Council based on the documents underlying the establishment of the } \\
\text { Economic and Social Council. In addition, the duties and authority of } \\
\text { the Economic and Social Council as a committee of the United } \\
\text { Nations will also be explained in this article, as well as the roles of } \\
\text { the Economic and Social Council in cooperation with the agencies of } \\
\text { the United Nations, which not only affect the continuity of the } \\
\text { United Nations, but also affect the lives of the subjects of } \\
\text { international law. The paper also comes with an analysis of the duties } \\
\text { and authority of the Economic and Social Council as a committee of } \\
\text { the United Nations. Other than that, analysis regarding the } \\
\text { implementation of the role of the Economic and Social Council in } \\
\text { cooperation with the agencies of the United Nations others joined } \\
\text { outlined in this paper. It is expected that the contents of this paper } \\
\text { can be useful not only as a reference for the learning process but also } \\
\text { as a form of a contribution to the related sciences Law International } \\
\text { and Regional Organizations. } \\
\text { Copyright@ } 2019 \text { VELREV. All rights reserved. }\end{array}$ \\
\hline
\end{tabular}

1. Introduction

Economic and Social Council (Economic and Social Council) or abbreviated with ECOSOC is one of the committees of the United Nations (UN), which plays a role in the economic and social sphere of the international community. Under Article 1 (3) of the United Nations (UN) Charter or the UN Charter, the UN determined that the goal is to promote cooperation and solve international problems in the field of economic, social, and others. Based on these clauses, it can be seen that the Economic and Social Council plays an important role in the implementation of UN tasks in economic and social fields.

In addition, the formation of the Economic and Social Council is a form of performance of the United Nations who has been coordinating the various activities in the field of economic and social. The Economic and Social Council may cooperate with the various agencies on the outside, such as governmental institutions as well as in the United Nations, such as UN agencies, and promote action in helping to address various issues related to the economic and social among UN member states. Facts relating to the 
activities of Economic and Social Council also made some people want to know more relating to the fundamentals of the establishment, duties, and authority, as well as a variety of cooperation undertaken by the Economic and Social Council.

\section{Method}

The method used in this article is normative analysis, in which its resources come from secondary documents, such as books, journals, thesis, and internet. The juridical method is also applied for this article and during the research process, the Author reviews regulations and international treaties regarding the topic. The normative analysis is also known for its interview methods towards experts on the discussed field.

\section{Analysis or Results}

\subsection{History Formation Economic and Social Council}

During World War I, the cooperation between each country in economic and social fields are formed due to their membership in some public union, among others in the Wheat Executive (1916) and Allied Maritime Transport Council (1917). ${ }^{1}$ However, the formation of the Economic and Social Council constituted by the League of Nations (LBB) were assessed as having failed in demonstrating its role in economic and social arrangements in the international sphere. The lack of regulation on the measures taken to ensure the social welfare of the international community and economic activities were not listed in the Covenant of the League of Nations. Economic and social problems are not written explicitly in a particular article, but implicitly stipulated in the preamble of the Covenant and Article 23, paragraph (e) of the Covenant, which reads as follows:

Preamble:

"THE High Contracting Parties,

In order to promote international cooperation and to Achieve international security

by the acceptance of obligations not to resort to war, by the prescription of open, just and honorable relations between nations,

by the firm establishment of the understandings of international law as the actual rule of conduct among Governments, and

by the maintenance of justice and a scrupulous respect for all treaty obligations in the dealings of organized people one another,

agree to this Covenant of the League of Nations. "2

Article 23 (e):

"Subject to and in accordance with the provisions of international conventions existing or hereafter to be the agreed upon, the Members of the League:

(E) will the make provision to secure and maintain freedom of communications and of transit and equitable treatment for the commerce of all Members of the League.

In this connection, the special necessities of the regions devastated during the war of 1914-1918 shall be borne in mind; "3

1 Philippe Sands QC and Pierre Klein, (2009), Bowett's Law of International Institutions, Ed.

5, Cet. 10, London: Thomson Reuters (Legal) Limited, p. 53.

2 League of Nations. (1919). the Covenant of the League of Nations, Preamble.

3 Ibid, Ps. 23 (e). 
Because there were no regulations specifically concerning the establishment of an Economic and Social Council, there is no accountability in the Assembly and Council to issues of international economic life and no LBB organ responsible for this. ${ }^{4}$ Although there are councils engaged in the economic and social matters, however they only consist of advisory committees or advisory committees. In addition, there are a number of auxiliary (subsidiary) committees on such matters, such as the Fiscal Committee, the Committees of Statistical Experts, the Coordination Committee and the International Loan Contracts Committee. ${ }^{5}$

Although the League of Nations (LBB) does not have a principal economic and social council, LBB in practice to impose the will to keep a handle related issues of economic and social nature, contrary to the will of its own. ${ }^{6}$ General depression (the Great Depression) that occurred in 1928 to 1931 making LBB issuing an idea to hold conferences to discuss economic issues, including the Monetary Conference held in 1933 and the World Economic Conference held in 1927. From the conference, produced a variety of movements, such as lending to rebuild countries after World War I, including Austria and Bulgaria. In addition, the supporting organizations, such as the International Relief Union, Bank for International Settlements, and the Communications and Transit Organization, was formed. LBB also formed a committee called the Committee Bruce in 1939, where the committee tasked to evaluate the activities of LBB in economic and social fields. The results from the formation of the committee are proposing that the Council escape its responsibility to deal with issues related to economic and social then make a separate Central Committee and consists of 24 representatives of the government as well as eight more experts. ${ }^{7}$

In the period of World War II, the Allies made a joint body which aims to allocate different materials and sources of wealth in order to win the war. At the same time also, various international bodies engaged in economic and social fields began to be formed, including the Food and Agriculture Organization (FAO) established by the United Nations Conference on Food and Agriculture, held in May 1943, the United Nations Relief and Rehabilitation Administration (UNRRA) formed by 44 governments in November 1943, and the formation of the International Monetary Fund (IMF) and the International Bank for Reconstruction and Development (IBRD) through the Bretton Woods Conference in July 1944. in December 1944, ${ }^{8}$

Look at the history of the League of Nations in addressing various social problems in the world economy and international, then came the idea that the need for a body that is both the principals and specialized to deal with these problems. Moreover, the existence of specialized organizations that

4 Sri Setianingsih Suwardi, Introduction to the Law of International Organizations, p. 306.

5 J. Pareira Mandalangi, 1986, Triangle Legal International Organizations: Book 1 An Introduction mode, Bandung: Binacipta Publishers, p. 83

6 Ibid.

7 Ibid.

8 Philippe Sands QC and Pierre Klein. (2009). Bowett's Law of International Institutions. Ed.

5, Cet. 10, London: Thomson Reuters (Legal) Limited, p. 54. 
have long stood coupled with the development organizations of any new shows how the need for coordination between these organizations to address economic and social problems, so that it became the basis of the establishment of the Economic and Social Council as a the principal agency in the United Nations (UN). ${ }^{9}$ The idea that the United Nations should participate in economic and social cooperation emerged from the thinking of the Allies of World War II that finally poured into the Dumbarton Oaks proposals were drawn up in $1944 .{ }^{10}$ In addition to these ideas, the Dumbarton Oaks also introduces the concept of mutual relation peace and security with the state of the economy. ${ }^{11}$ At first, the Economic and Social Council was initiated in the Dumbarton Oaks as a specialized agency under the United Nations General Assembly, but by the 1945 United Nations Conference on International Organization in San Francisco, Economic and Social Council established as a principal organ of the UN. The first meeting of the Economic and Social Council held in December 1964 and resulted in the establishment of the United Nations Commission on Human Rights (UNCHR) with Eleanore Roosevelt as one of the key members of the agency. ${ }^{12}$ In 1991, the UN General Assembly called for a reassessment of the specialized agencies of the Economic and Social Council. ${ }^{13}$ Council also requested the Secretary-General to implement various programs to reconstruct and rejuvenate the United Nations in the economic, social and other fields related to, among others to reconstruct the order of several bodies, increased diversity in terms of geography for each representative of the country, strengthening the role of the commission regional, as well as the transformation of the specialized agencies and other bodies. ${ }^{14}$ This is done with the aim to improve the efficiency of the function of the specialized agencies to be more responsive in handling economic cooperation and promoting development for developing countries. ${ }^{15}$

\subsection{Membership Composition of the Economic and Social Council}

Economic and Social Council is led by a President with a time of leadership for a year. President of the Economic and Social Council selected from small to medium strength Economic and Social Council. On July 26, 2018, has been elected Her Excellency Inga Rhonda King of Saint Vincent and the Grenadines is the President of the Economic and Social Council in 2019 to replace Her Excellency Marie Chatardová of the Czech Republic. Economic and Social Council consists of 54 members. In the past, members of the Economic and Social Council consists of 18 people, but an amendment made to the United Nations Charter in 1965. At that time, the number of members of the Economic and Social Council which was originally made up of 18

9 Ibid.

10 Thomas G. Weiss and Sam Daws, ed. (2018). The Oxford Handbook on the United Nations, Ed. 1, Cet. 2, Oxford: Oxford University Press, p. 139.

11 Ibid.

12 Jussi M. Hanhimäki, (2015). The United Nations: A Very Short Introduction. Ed. 2.

Oxford: Oxford University Press, p. 112.

13 Philippe Sands QC and Pierre Klein, Bowett's Law of International Institutions, p. 54.

14 Ibid.

15 Ibid. 
people grew to 27 people, according to the results issued by Assembly Resolution general (General Assembly) of the United Nations No. 1991 B (XVIII). Then, an amendment to the UN Charter redone through Resolution No. 2847 (XXVI) in 1973, so the number of members of the Economic and Social Council increased to 54 people. Every year, members of the Economic and Social Council selected a total of 18 members for a term of 3 years and a member of the stops can be immediately re-elected for the next stage. ${ }^{16}$ Under the UN Charter Article 61 paragraph 4, each member state Economic and Social Council has a representative in the board. ${ }^{17}$

Unlike the UN Security Council, the Economic and Social Council has no permanent members. However, countries that are members of the Big Five which is a permanent member of the UN Security Council, namely the United States, Britain, France, Russia, and China, always elected to the Economic and Social Council. In practice, the election of members of the Economic and Social Council applied the principle of equality (the principle of equality) and in every election of its members always seek representation from each country is more diverse in terms of geography, economic background and social circumstances. In addition, the allocation of the distribution of the number of seats of members of the Economic and Social Council is also considering various interest groups based on the amendment of Article 61 of the UN Charter, including groups of Africa, Asia, ${ }^{18}$ Each UN member country which is not a member of the Economic and Social Council has the freedom to follow the Economic and Social Council meetings when the issues discussed in this session have a relationship with the UN member states that are not members of the Economic and Social Council. It is regulated in Article 69 of the UN Charter, which reads:

"The Economic and Social Council shall invite any Member of the United Nations to Participate, without vote, in its deliberations on any matter of particular concern to that Member."19

\subsection{Voting System}

In the Economic and Social Council, every member has one vote. The decisions in the trialware are taken based on the most votes. It is based on Article 67 of the UN Charter. In addition, the Economic and Social Council convened twice a year with a duration of one month.

\subsection{The structure of the Economic and Social Council Committee}

Economic and Social Council has a committee that contains subsidiary bodies which aim to simplify the handling of problems in the field of economic and social variety. Article 68 of the UN Charter authorizes the Economic and Social Council to set up commissions, so that the Economic and Social Council itself has formed three plenary sessional committees consisting of a committee of economic, social, programs, and cooperation, and there are also some standing committees or

\footnotetext{
16 J. Pareira Mandalangi, Triangle Legal International Organizations: Book 1 An Introduction mode, p. 84.

17 The United Nations. (1945). Charter of the United Nations. Ps. 61 paragraph (4).

18 Philippe Sands QC and Pierre Klein, Bowett's Law of International Institutions, p. 55.

19 The United Nations. (1945). Charter of the United Nations, Ps. 69.
} 
permanent committees. ${ }^{20}$ In respect of the meeting of Economic and Social Council, Economic and Social Council frequent group sessions short and several preparatory meetings, and there is also a session of the annual meeting held every in July, which was attended by cabinet ministers and other officials to discuss the problems great relevant economic, social, and environmental. ${ }^{21}$ In addition, the Economic and Social Council are also working together in his work with the programs of the United Nations (UNDP, UNEP, UNFPA, UN-Habitat, and UNICEF), as well as specialized agencies (FAO, ILO, WHO and UNESCO ). ${ }^{22}$ Economic and Social Council was divided into several committees within the structure of committees. The division of committee structures Economic and Social Council are as follows:

a. Economic Commission Regional (Regional Economic Commission), whose task is to promote economic development in each region and enhance economic cooperation of countries in the region both among countries in the region and with countries in other regions, consisting of Commission economic for Africa (Economic Commission for Africa / ECA), headquartered in Addis Ababa, Ethiopia; Economic and Social Commission for Asia and the Pacific (Economic and Social Commission for Asia and the Pacific / ESCAP), headquartered in Bangkok, Thailand; Economic and Social Commission for Latin America and the Caribbean (Economic Commission for Latin America and the Caribbean / ECLAC) located in Santiago, Chile; Economic Commission for Western Asia (Economic and Social Commission for Western Asia / ESCWA) based in Beirut, Lebanon;

b. Eight functional commissions, whose task is to create and provide recommendations related to the issues in accordance with their competence and consists of the Commission on Population and Development, the Commission on Statistics, the Commission on Social Development, the Commission on the Forum on Forests, the Commission on Drugs Narcotics Commission on Prevention of Crime and justice, the Commission on Science and Technology for Development and the Commission on the Status of Women;

c. Three permanent committees, which of the Committee on Program and Coordination, Committee on Governmental Organization, and the Committee on Negotiations with Intergovernmental Agencies;

d. Bodies of Experts, which was made in order to discuss the problems of development cooperation, geographical names, the management of geospatial information, public administration, international cooperation on tax matters, the delivery of dangerous goods, as well as the rights of economic, social, and cultural ;

e. Other bodies, including the Permanent Forum on Indigenous Issues, the International Narcotics Control Board, and the high-level political forum. ${ }^{23}$

\section{Duties and Powers of the Economic and Social Council as One of the Committee of the United Nations}

Economic and Social Council described as "the pivot of the economic and social organization under the auspices of the UN" or the midpoint of the economic and social organization under the auspices of the United Nations. ${ }^{24}$ Duties and authority of the Economic and Social Council as a committee of

20 Philippe Sands QC and Pierre Klein, Bowett's Law of International Institutions, p. 58.

21 United Nations Information Center. (2017). Basic Facts about the United Nations, Ed. 42,

New York: United Nations, p. 13.

22 Ibid.

23 Ibid.

24 Philippe Sands QC and Pierre Klein, Bowett's Law of International Institutions, p. 55. 
the United Nations stipulated in the UN Charter Article 62 to 66. The duties and authority of the Economic and Social Council based on those articles are divided into some form of activity, other conduction:

\section{Doing Various Studies}

Pursuant to Article 62 paragraph (1) of the UN Charter, the Economic and Social Council has the authority to conduct various studies and reports related to issues of economic, social, cultural, educational, and other related issues. To perform these studies, requests for the implementation of the study submitted to the Secretary-General, and to the regional commissions, the ad hoc committee, as well as the specialized agencies concerned. Studies carried out formed the basis for the formation of the various recommendations issued by the Economic and Social Council. Examples of studies carried out by the Economic and Social Council include studies on the economic development of the countries that are still considered to be lagging behind in economic terms. In addition, the Economic and Social Council can also undertake special studies ${ }^{25}$

\section{Make Recommendations}

Pursuant to Article 62 paragraph (2) of the UN Charter, the Social Economic Council can make a variety of recommendations. Based on the article as well, these recommendations were made with the aim of promoting respect or respect for human rights and fundamental freedoms for all human beings. ${ }^{26}$ The nature of the recommendations given is not binding for UN member states. The word 'recommendation' itself signifies non-obligatory nature of a resolution, which in practice is used some terminology, such as 'commends' (respect), 'Refers' (referring), and 'calls upon' (ask). The nature of the recommendations is addressed to UN member states and sometimes asks these countries to commit an act of the legislature. ${ }^{27}$

\section{Formulate Conventions}

Duties and authorities of other Economic and Social Council are authorized to formulate conventions. Pursuant to Article 62 paragraph (3) of the UN Charter, the Economic and Social Council has the authority to formulate the conventions that will be discussed in the forum of the UN General Assembly. ${ }^{28}$ Conventions made by the Economic and Social Council are conventions in accordance with the scope of competence of the handle, which is in the economic and social fields. Examples of conventions made by the Economic and Social Council, among others, is the Draft Protocol Relating to the Status of Stateless Persons who discussed the UN Conference in 1954 and the Convention on the Prevention and Punishment of the Crime of Genocide. Later, when the General Assembly approved the convention discussed in the forum, it will be adopted and the convention was opened for signature by the UN member states that are willing.

25 Ibid, p. 56.

26 The United Nations. (1945). Charter of the United Nations, Ps. 62 paragraph (2).

27 Philippe Sands QC and Pierre Klein, Bowett's Law of International Institutions, p. 56.

28 The United Nations. (1945). Charter of the United Nations, Ps. 62 paragraph (3). 


\section{Conferences held}

Economic and Social Council has the authority to hold conferences. It is stipulated in Article 62 paragraph (4) of the UN Charter. At the conference, the problems related to the economic and social will be discussed in accordance with the competence of the Economic and Social Council. The conferences that do could be a conference of non-governmental, such as the World Population Conference in 1954 and the conferences which consist of experts in economic and social fields, as examples of the UN Scientific Conference on the Conservation and utilization of Resources in 1949. ${ }^{29}$ Thus, the conferences made by the Economic and Social Council is not only limited to a conference among representatives of state government. In fact there are also conferences that combine elements of government with elements of nongovernment, as an example of the World Conference against Racism, Racial Discrimination, Xenophobia and Related Intolerance held in Durban, South Africa, between August and September 2001, and the World Conference on Disaster Reduction held in Kobe, Japan, in January 2005. ${ }^{30}$

Duties and authority of the Economic and Social Council were also set out in Article 63, which in paragraph (1) provides that the Economic and Social Council has the authority to deal with the agencies mentioned in Article 57. ${ }^{31}$ The sound of Article 57 in question is as follows:

1. The various specialized agencies, established by intergovernmental agreement and having wide international responsibilities, as defined in their basic instruments, in economic, social, cultural, educational, health, and related fields, shall be brought into relationship with the United Nations in accordance with the provisions of Article 63.

2. Such us agencies brought into relationship with the United Nations are hereinafter referred to as specialized agencies. ${ }^{32}$

Based on the above article, it is known that the deal is done by the Economic and Social Council with the specialized agencies established under an intergovernmental agreement and having international responsibilities. Specialized agencies is also engaged in the fields of economic, social, cultural, educational, health and other related fields. In addition, the Economic and Social Council may cooperate with nongovernmental organizations (NGOs) to discuss the economic and social problems. Until September 2016, it was noted that there are 4,665 NGOs have consultative status with the Economic and Social Council. ${ }^{33}$ In 1968, created a set of categories of NGOs and their status in cooperation with the Economic and Social Council. NGO Category I has wide access in the handling of economic and social problems, which he can submit agenda points. In addition, the NGO Category II has interests more specifically, to observe meetings of the Economic and Social Council,

29 Philippe Sands QC and Pierre Klein, Bowett's Law of International Institutions, p. 56.

30 Ibid.

31 The United Nations. (1945). Charter of the United Nations, Ps. 63 paragraph (1).

32 Ibid, Article 57.

33 United Nations Information Center, Basic Facts about the United Nations, p. 16. 
but can only enter written statements related to specific issues. ${ }^{34}$ Category III NGOs are allowed to contribute directly correspond to demand an official of the Economic and Social Council. ${ }^{35}$

Economic and Social Council also has the duty and authority of which is regulated in Article 64 paragraph (1), wherein the article states that the Economic and Social Council is authorized to request regular reports from specialized agencies. ${ }^{36}$ In the request regular reports the Economic and Social Council can regulate the holding of a meeting with members of other UN agencies as well as with the special. Reports requested will be used as ingredients drafting recommendations based on competence made by the General Assembly. ${ }^{37}$ Pursuant to Article 64 paragraph (2), explained that the results of the reports that have been requested can be communicated to the UN General Assembly. ${ }^{38}$ Within the scope of the UN General Assembly, reporting Economic and Social Council will be discussed in the Third Committee or the Committee on Social, Humanitarian and Cultural (Social, Humanitarian, and Cultural Committee), but this should not rule out the possibility, especially in the handling of human rights, for discussed in the First Committee or the Political Committee or the Sixth Committee or Legal Committee, may even be discussed in the Special Political Committee.

Article 65 of the Charter of the United Nations set the duties and authority of the Economic and Social Council related to the coordination with the Security Council. In the article, explained that the Economic and Social Council to provide information to the Security Council and can assist the Security Council in accordance with the request. In addition to the Security Council, the Economic and Social Council also has the duty and authority in accordance with the competence to implement the recommendations of the UN General Assembly. It is stipulated in Article 66 paragraph (1) of the Charter. Economic and Social Council can also take action in accordance with what has been requested by the UN member states and specialized agencies with the approval of the General Assembly. Assistance to other organs, states, and specialized agencies carried out by the Economic and Social Council can be seen from the programs implemented by the Economic and Social Council on a regular basis by specialized agencies. Then, there is also an Expanded Program of Technical Assistance (EPTA) carried out by the Economic and Social Council along with ten agencies joint special Technical Assistance Committee (TAC) to discuss policies that can be entrusted to the Technical Assistance Board (TAB) in which the specialized agencies that participate in it. ${ }^{39}$ In addition, there is also a program called Special Fund which is a voluntary contribution given by the UN member states. The program developed in 1958 was supervised also by the Governing Council and the

34 Matthew Hilton. (2009) Prosperity for All: Consumer Activism in an Era of Globalization, Ed. 1, Cet. 1, Ithaca: Cornell University Press, p. 112.

35 Ibid.

36 The United Nations. (1945). Charter of the United Nations, Ps. 64 paragraph (1).

37 Ibid.

38 Ibid, Ps. 64 paragraph (2).

39 Philippe Sands QC and Pierre Klein, Bowett's Law of International Institutions, p. 57. 
Consultative Board. EPTA and the Special Fund, was eventually into one program, namely the UN Development Program (UNDP).

\section{Cooperation Economic and Social Council in cooperation with the Agency Conducting-agency of the United Nations Others}

As described in Section Duties and Powers of the Economic and Social Council, Article 63 of the UN Charter explains that the Economic and Social Council has the authority to enter into agreements with agencies as stated in Article 57 of the charter. The following are examples of forms of cooperation Economic and Social Council in cooperation with the agencies of the UN, as an example of cooperation between the United Nations High Commissioner for Refugees (UNHCR) and the United Nations Conference on Trade and Development (UNCTAD).

1. United Nations High Commissioner for Refugees (UNHCR)

United Nations High Commissioner for Refugees (UNHCR) is a subsidiary body established by the UN General Assembly resolution No. 319 (IV) in 1949. UNHCR made to continue the duties and authority of the International Refugee Organization after the activities of the organization stopped. ${ }^{40}$ The duties and authority of UNHCR stipulated in the Statute of the Office of the UN High Commissioner for Refugees are also attached to the UN General Assembly Resolution No. 428 (V) (1950). Establishment of UNHCR itself is underlain by the refugee crisis since World War II, where there are one million people displaced after World War II $^{41}$ and spread in various regions of the world, such as Europe 400,000 people displaced from their homes, and remained that way until 1951 and the number of refugees who come from countries in Eastern Europe are dominated by communism. ${ }^{42}$ In 1954 , UNHCR receives the Nobel Peace Prize because among the nominees of the Nobel Peace Prize that no one can reach the criteria stated in the will of Alfred Nobel. ${ }^{43}$ In the initial formation, UNHCR has contributed to handle cases related to ensuring the rights of refugees. For example, when the Hungarian Revolution of 1956, Hungary's 200,000 residents to flee to Austria. ${ }^{44}$ Be aware that Hungary is a prima facie refugee or the first sighting of the refugees, the UNHCR also helps them to be able to evacuate the process and residence. ${ }^{45}$ At the beginning of the establishment of the UNHCR office on January 1, 1951, the period of the mandate of UNHCR had not been renewed periodically, until finally in 2003, it was determined that there was no period of UNHCR's mandate so that UNHCR continues to serve until the refugee problem is resolved.

Six main tasks of UNHCR itself as follows:

$40 \quad$ Ibid, p. 67.

41 United Nations Information Center, Basic Facts about the United Nations, p. 36.

42 Jérôme Elie. (2010) "The Historical Roots of Cooperation between the UN High Commissioner for Refugees and the International Organization for Migration," Global Governance16 International Migration (July-September), p. 347.

43 The Nobel Prize, "the Nobel Peace Prize in 1954", https://www.nobelprize.org/prizes/peace/1954/summary/, accessed 15 November 2018.

44 United Nations High Commissioner for Refugees, "History of UNHCR", http://www.unhcr.org/history-of-unhcr.html, accessed 15 November 2018.

45 Ibid. 
a. Protection of vulnerable refugees;

b. Provision of shelter for refugees in need;

c. Advocacy to help change policies and services that affect the refugees;

d. Ensure that refugees get adequate health care;

e. Helps maintain and restore each individual refugees rebuild their lives;

f. Make a blueprint, the Global Needs Assessment, in order to plan action in the time of crisis. ${ }^{46}$

UNHCR also ensure that the refugees do not return to their home country against their will, because when that happens, the refugees will be vulnerable to become victims of discrimination, violence and persecution. UNHCR is also establishing various forms of cooperation with NGOs, organizations under the auspices of the United Nations, as well as groups based on religion and belief in order to help each other to deal with ensuring the rights of refugees and asylum seekers.

Associated with the cooperation of the Economic and Social Council with the UNHCR, UNHCR's own reporting annually to the General Assembly through the Economic and Social Council. ${ }^{47} \mathrm{UNHCR}$ reporting done to the Economic and Social Council is oral. Such reporting is given at the beginning of November in the Committee forum Social, Humanitarian and Cultural (Third Committee). The third committee was also considered and adopted three resolutions related to UNHCR, including:

a. The Resolution on the Work of the Office of the United Nations High Commissioner (Omnibus Resolution);

b. The Resolution on the enlargement of the Executive Committee of the Program of the United Nations High Commissioner for Refugees;

c. The Resolution on Assistance to Refugees, returnees and displaced persons in Africa. ${ }^{48}$

\section{United Nations Conference on Trade and Development (UNCTAD)}

United Nations Conference on Trade and Development (UNCTAD) is one of the organs of the United Nations General Assembly established pursuant to resolution 1995 (XIX) (1964). ${ }^{49}$ UNCTAD itself is based in Geneva, Switzerland. UNCTAD conference held every four years, which was attended by 194 ministers of state in the economy and the last UNCTAD conference is the fourteenth conference held in Nairobi and discuss finance, sustainable development, and climate change. ${ }^{50}$ The main functions of UNCTAD is to promote international trade and the development of a variety

46 United Nations High Commissioner for Refugess, "What We Do", http:/ / www.unhcr.org/what-we-do.html, accessed 15 November 2018.

47 Philippe Sands QC and Pierre Klein, Bowett's Law of International Institutions, p. 67.

48 United Nations High Commissioner for Refugees, "United Nations General Assembly", http:/ / www.unhcr.org/ united-nations-general-assembly.html, accessed 15 November 2018. 49 Ibid, p. 69.

50 United Nations Conference on Trade and Development, "UNCTAD Annual Report 2016", https://unctad.org/en/pages/PublicationWebflyer.aspx?publicationid=1857, accessed 15 November 2018. 
of occasions, particularly in developing countries. ${ }^{51}$ In addition, UNCTAD is also moving to help reduce poverty.

UNCTAD has three main areas: research and analysis, intergovernmental consensus building with consideration and technical cooperation conducted by diverse partners. ${ }^{52}$ The forms of the real contribution of UNCTAD include policy recommendations, participation in various international meetings, and various forms of large-scale reporting. Examples of publications issued by UNCTAD among others, is the Trade and Development Report, the World Investment Report, Economic Development in Africa Report, Least Developed Countries Report, UNCTAD Handbook of Statistics, Economic Information Report and Review of Maritime Transport. ${ }^{53}$ The committee structure of UNCTAD itself is composed of the executive body, namely the Trade and Development Board and subsidiary bodies consisting of commissions, including the Commission on Investment, Technology, and Related Financial Issues, the Commission on Trade in Goods and Services, and Commodities and the Commission on Enterprise, Business Facilitation and Development. ${ }^{54}$

UNCTAD related to cooperation in the sphere of Economic and Social Council, UNCTAD holding a summit in the realm of the Economic and Social Council together with other organizations, such as the World Bank, the International Monetary Fund (IMF) and the World Trade Organization (WTO). This high-level meeting held to discuss the state of the world economy and there is also a segment of the thematic debate that the discussion does away with the state of world trade, investment, as well as how to increase the economy of these countries, especially countries that are still in need of more funding.

\section{Analysis of Implementation of Duties and Authorities of the Economic and Social Council}

Related to the duties and authority of the Economic and Social Council, Economic and Social Council to be one of the main organs of the United Nations (UN) has assessed the performance of the less effective. Article 7 of the UN Charter states that the United Nations has six principal organs, including the General Assembly, Security Council, Economic and Social Council, the Trusteeship Council (now defunct), International Court of Justice, and the Secretariat. ${ }^{55}$ Basically, the mandate addressed to the Economic and Social Council aims to provide authority for the Economic and Social Council to address issues related to economic and social. The compilers of the UN Charter negotiators found the economic depression that occurred in the 1930s became one of the main causes of World War II so it will be economic security is a crucial issue that could be said to be

\footnotetext{
51 Philippe Sands QC and Pierre Klein, Bowett's Law of International Institutions, p. 69.

52 United Nations Information Center, Basic Facts about the United Nations, p. 32.

53 Ibid.

54 Philippe Sands QC and Pierre Klein, Bowett's Law of International Institutions, p. 69.

55 Anthony Aust. (2010). Handbook of International Law, Ed. 2. Cet. 1, Cambridge: Cambridge University Press, p. 189.
} 
handled.$^{56}$ There are some things that cause a lack of effective performance Economic and Social Council. First, members of the Economic Council of only 54 countries did not adequately represent the entire UN member states consisting of 193 member states and 2 countries acting as observers. ${ }^{57}$ Thus, the Economic and Social Council membership only covers $28 \%$ of the total UN membership. ${ }^{58}$ In addition, one of the reasons why the Economic and Social Council less effective in carrying out its duties and authorities are due to financial policies more countries to reflect on the policies issued by financial institutions internationally, such as the International Monetary Fund (IMF), The World Bank, and World Trade Organization (WTO).

Handling problems the world economy held by the institutions, known as the Three Sisters, the IMF, the World Bank, and World Trade Organization (WTO). IMF and World Bank are institutions of Bretton Woods. The IMF is an institution whose task is to provide loans to countries that need to do the stabilization of the country's currency and maintain the international financial markets. ${ }^{59}$ The World Bank itself is a multilateral institution and has the authority to lend to the government and government agencies, where the funds are used for the development of various projects. WTO itself is a specialized agency whose job is to keep international trade runs smoothly and to try to reduce the barriers that exist in international trade. There are similarities in terms of voting between the IMF and the World Bank, where the two institutions calculate voting based on their contribution to the institution, which is the biggest funder. In 2015, the United States holds $16 \%$ of the votes of the G7 countries, which is the largest industrial countries made up of Britain, Canada, France, Germany, Italy, Japan, ${ }^{60}$ Based on this, it can be seen that most of the approved policy is the policy chosen by the developed countries and countries with high industrial development. This resulted in a lack of representation of the voices of developing countries and the use of policies that lead to advanced economies. This is contrary to the principles of the Economic and Social Council are more willing to embrace countries with economic backgrounds are more diverse, ranging from developed countries, developing countries, to countries that still require economic assistance. This principle can be seen from the Economic and Social Council that takes into account the composition and diversity of member countries of the council as well as the construction of the regional commissions that take care of various economic problems in various countries with different economic backgrounds. In addition, the nature of the Economic and Social Council that they report to the UN General Assembly under the Charter makes the board does not have final authority to make decisions related to issues within the scope of the Economic and Social Council submitted.

\footnotetext{
56 Jussi M. Hanhimäki. (2015). The United Nations: A Very Short Introduction, Ed. 2. Oxford: Oxford University Press, p. 41.

57 Ibid.

58 Joseph E. Schwartzberg. (2013). Transforming the United Nations System: Designs for a workable World, Tokyo: United Nations University, p. 98.

59 Jussi M. Hanhimäki, The United Nations: A Very Short Introduction, p. 42.

60 Ibid, p. 43.
} 
In addition to the above problems, the Economic and Social Council has a broad scope focus on issues to be addressed, ranging from economic, social, education, culture and health, and the environment, so that the board's work should be assisted by the specialized agencies and commissions. This causes an imbalance in the handling problems, although these problems are still included within the competence of the Economic and Social Council. According to HG Nicholas, Economic and Social Council had 'better performance in handling economic issues rather than social issues, better addressing the regional rather than global in scope, ${ }^{61}$

Came an idea to reform the Economic and Social Council. This reform idea emerged to reconstruct and revitalize the United Nations performance in the spheres of social, economic, and another relevant scope. Increasing the effectiveness, the performance of the board, as well as commissions under it could be a consideration Economic and Social Council in 1950. This consideration is planned to be done by establishing an ad hoc committee that has the task of reviewing the performance of the organization as well as subsidiary bodies underneath. There have been many actions taken to reform the Economic and Social Council, among others, is to make changes in the procedures, roles, methods of action are used, up to a change in membership. The shape of the reform was reviewed by an ad hoc committee or panel containing experts, and finally brought to the General Assembly in order to take a decision. In 1975, a special session of the UN General Assembly was held to discuss the structural changes within the UN system to increase cooperation in the field of international economy. The session resulted in several recommendations regarding the most recent tasks for the Economic and Social Council as well as to align the duties and powers of the Economic and Social Council which still has a relationship with the powers and duties of the General Assembly. Statements made at the session resulted in the UN General Assembly Resolution 32/197, ${ }^{62}$ Reform does not stop there, but also the reforms held back for a second time in 1986, which resulted in General Assembly resolution 50/227 which it provides policy guidance role to the UN General Assembly and further confirm the coordinating role of the Economic and Social Council. ${ }^{63}$ The provision of policy guidance role to the General Assembly, under Article 18 of the resolution, made the UN General Assembly became the highest intergovernmental mechanism that is both in terms of handling issues related to the economic, social, until other related matters. Increasing the effectiveness of the Economic and Social Council also initiated in the third reform in 2003. The idea was formulated in the reform proposals that are in the report entitled In Larger Freedom. This idea is also to be one idea that is carried in the 2005 World Summit and set in Resolution $60 / 1$.

Reform of the Economic and Social Council to be one way to increase the effective functioning of the Economic and Social Council itself. With the

61 Aneek Chatterjee. (2010). International Relations Today: Concepts and Applications (Noida: Dorling Kindersley, 2010), p. 99.

62 Thomas G. Weiss and Sam Daws, ed. (2008). The Oxford Handbook on the United Nations, Ed. 1, Cet. 3, Oxford: Oxford University Press, p. 144.

63 Ibid, p. 145. 
reform, the measures and the methods used to deal with problems in the economic and social sphere will be more able to adapt to the times. In addition, the policy-related reforms, such as creating a policy review, to increase knowledge of an issue or relevant council policies made in certain countries, so as to know it can facilitate the Economic and Social Council to recommend an activity related to the policy. Reform is not only done on the basis of the observations in the scope of the United Nations, but it would be better if balanced with research, analysis, and review policies made by experts, researchers, and analysts who are engaged in international organizations, especially the Economic and Social Council. Thus, in addition to the appearance of the views more fresher and probably had never been mentioned before, these views could represent the international community needs to be an institution that can maximize the potential to move in accordance with their competence.

\section{Analysis of Implementation of the Cooperation Economic and Social Council with the Agency-Agency of the United Nations Others}

1. United Nations High Commissioner for Refugees (UNHCR)

Examples of the implementation of the cooperation with the Economic and Social Council UNHCR is the formulation of the Global Compact on Refugees which was approved with 174 voting results disagree agree to 1 on 14 November 2018. The only country that did not agree to the Global Compact on Refugees is USA, it is caused by incompatibility in the Global Compact policy with the policy made by the United States against the refugees, where the refugees who entered illegally would be arrested and prosecuted because it was feared would threaten the country's sovereignty. In addition, another reason the United States did not agree to the Global Compact on Refugees because the United States wants to keep using immigration-related regulations that have been set by the US government, so that policies related to immigration in the country does not refer to what has been formulated in the Global Compact on Refugees. The Global Compact on Refugees is not only defined by the UNHCR and the Economic and Social Council, but also the relevant UN agencies, governments of member countries, as well as the Civil Society, the NGOs engaged in the protection of refugees.

The Global Compact on Refugees contains two parts, including the Comprehensive Refugee Response Framework (CRRF) and program of action, which are set out in section CRRF implementation mechanisms and their way of running it. CRRF itself a result of the adoption of the New York Declaration on Refugees and Migrants (A / RES / 71/1). There are new things related to guaranteeing the rights of refugees in the Global Compact on Refugees, which guarantees the rights of the refugees who had to leave their homes because of natural disasters is also set in the Global Compact on Refugees. In paragraph 8 of part of the action program, explained that the results of the embodiment of actions arranged among others:

a. Widen the foundations for ongoing support for the refugees and the countries of the refugees container through cooperation with various stakeholders; 
b. Humanitarian response and development of a more robust and predictable;

c. Increased investment in human resources through education and exposure resilience opportunities related activities for the refugees and the countries of the refugees container;

d. Strengthen the focus on addressing underlying causes and planning to formulate a solution. ${ }^{64}$

The Global Compact on Refugees is one example of the implementation of the cooperation between the Economic and Social Council with other United Nations agencies. It is caused first, by the scope of the discussion of the Global Compact which covers issues related to refugees remains the domain of social problems. This is in accordance with the authority and competence and the Economic and Social Council contained in the UN Charter. In addition, the Global Compact on Refugees does not only involve the Economic and Social Council as well as the UNHCR, but also other actors, such as governments of the UN member states as well as the Civil Society consisting of NGOs. The participation of NGOs in the approval of the Global Compact on Refugees is a clear manifestation of the implementation of the duties and authority of the Economic and Social Council related to cooperation with NGOs. Thus, the implementation of this cooperation is also a realization of the application of duties and authorities of the Economic and Social Council in accordance with that stated in the UN Charter. Indicators of success of this implementation is the approval of the Global Compact on Refugees which is expected to be a reference for UN member states to regulate issues related to ensuring the rights of refugees and IDPs in the country. implementation of this cooperation is also a realization of the application of duties and authorities of the Economic and Social Council in accordance with that stated in the UN Charter. Indicators of success of this implementation is the approval of the Global Compact on Refugees which is expected to be a reference for UN member states to regulate issues related to ensuring the rights of refugees and IDPs in the country. implementation of this cooperation is also a realization of the application of duties and authorities of the Economic and Social Council in accordance with that stated in the UN Charter. Indicators of success of this implementation is the approval of the Global Compact on Refugees which is expected to be a reference for $\mathrm{UN}$ member states to regulate issues related to ensuring the rights of refugees and IDPs in the country.

\section{United Nations Conference on Trade and Development (UNCTAD)}

Implementation of the cooperation between UNCTAD with the Economic and Social Council are holding high-level meetings with the Economic and Social Council, where the meeting of the representatives of UNCTAD, Economic and Social Council, the IMF, the World Bank, and WTO gathered to discuss trade and development, One example of high-level meetings this is a high-level meeting of the Economic and Social Council with UNCTAD,

64 United Nations High Commissioner for Refugees. (2018). The Global Compact on Refugees, para. 8 . 
the World Bank, IMF, and WTO held on 14-15 April 2014 in the Economic and Social Council Chamber, at UN Headquarters in New York, United States, The meeting was based by the Economic and Social Council resolution 2013/44 and the theme "Coherence, coordination and cooperation in the context of financing for sustainable development and the post-2015 development agenda". This meeting consisted of several sessions, ${ }^{65}$

There is an interesting thing on the implementation of the UNCTAD Conference 2014. At this conference, Indonesia's leadership role in UNCTAD. Ambassador or Dewatapri Edi Yusup elected by acclamation as one of the Vice President of the Trade and Development Board (TDB) representing the Asian region for the period September 2014-September 2015.66 With the election of him as the Vice President of TDB, then there is an opportunity for Indonesia to protect the developing countries in the negotiation process of UNCTAD Conference Preparatory Committee XIV in Lima, Peru. ${ }^{67}$ Earlier, Ambassador Triyono Wibowo was also elected President of the TDB for the period 2013-2014. At the time of the presidency, has carried out a mid-term review of the results of the thirteenth UNCTAD Conference in Doha, which is a reference to the preparation of the UNCTAD conference in 2016. In addition, at the conference in 2014, Ambassador Triyono Wibowo given an opportunity to explain the contribution of UNCTAD in the process preparation of post-2015 global development agenda to the second Committee of the UN General Assembly in October 2013 in New York, as well as participate in discussions UN ECOSOC High Level Meeting with the Bretton Woods institutions. ${ }^{68}$

Based on the example of the implementation of this cooperation, it was found that the Economic and Social Council and UNCTAD aligned with each other in forming a cooperative in order to boost the world economy. In addition, both institutions work together to form a container conference to discuss the current economic problems, so that the solution obtained in accordance with the times. The involvement of the IMF, World Bank, and the WTO is a form of implementation of Article 63 of the UN Charter which also refers to Article 57 of the UN Charter, which in practice the IMF, World Bank, and the WTO is the Specialized Agencies referred to it by the UN Charter. The shape of this cooperation can also align the ideas issued by the Economic and Social Council with the IMF, the World Bank, and WTO,

\section{Conclusion}

Economic and Social Council is an organ of the principals of the United Nations (UN), which was set up to resolve problems related to the economic

\footnotetext{
65 United Nations Conference on Trade and Development, "Special High-Level Meeting of ECOSOC with UNCTAD, the World Bank, the IMF, and the WTO", https:// unctad.org/en/pages/MeetingDetails.aspx?meetingid=549, accessed 15 November 2018.

66 Hasan Kleib, "World Leadership Appreciation Indonesia in UNCTAD", https://missionindonesia.org/2014/09/16/dunia-apresiasi-kepemimpinan-indonesia-di-unctad/, accessed 15 November 2018.

67 Ibid.

68 Ibid.
} 
and social of the member states of the United Nations and to enhance cooperation of member countries of the UN in general and the Economic and social specifically to address issues related to economic and social. Implementation of duties and authority of the Economic and Social Council still considered effective, because the number of members of the Economic and Social Council was rated slightly, Economic and Social Council that does not play a role initiators main policies, especially in the economic field, and diverse and the large amount of focus on the issue held by the Council economic and Social, so it takes a regular basis in terms of reform measures to handling problems. Cooperation between the Economic and Social Council with the agencies of the United Nations others provide impetus and simplify Settlement of issues related to economic and social. In addition, the partnership provides an easy to realize a real policy to address economic and social problems.

\section{References}

\section{Book}

Aust, Anthony. (2010). Handbook of International Law. Ed. 2. Cet. 1. Cambridge: Cambridge University Press

Bookmiller, Kirsten Nakjavani. (2008). Global Organizations: the United Nations. New York: Infobase Publishing.

Aneek, C. (2010). International relations today: Concepts and applications. Pearson Education India.

Gordenker, Leon. (2010). The UN Secretary-General and the Secretariat. Ed. 2. Cet. 1. New York: Routledge.

Hanhimäki, J. M. (2015). The United Nations: a very short introduction. Oxford University Press.

Hilton, M. (2009). Prosperity for all: Consumer activism in an era of globalization. Cornell University Press.

Kyrgyz Jr., Frederic L. (1993) International Organizations in their Legal Setting: Selected Documents. Minnesota: West Publishing Co.

Klabbers go, Jan. (2009). An Introduction to International Institutional Law. Ed. 2. Cet. 7. Cambridge: Cambridge University Press.

Lewis, C. (2012). UNHCR and international refugee law: from treaties to innovation. New York: Routledge.

MacKenzie, D. C. (2010). A world beyond borders: an introduction to the history of international organizations (Vol. 1). University of Toronto Press.

Mandalangi, J. Pareira. (1986)Triangle International Organization of Legal: Book 1 A Modus Introduction. Bandung: Publisher Binacipta.

De Marco, G., DeMarco, G., \& Bartolo, M. (1997). A Second Generation United Nations: For Peace and Freedom in the 21st Century. Routledge.

Moore, John Allphin. (2010). Encyclopedia of the United Nations. Ed. 2. New York: InfobasePublishing.

Pietsch, J., \& Clark, M. (Eds.). (2015). Migration and integration in Europe, Southeast Asia, and Australia: a comparative perspective. Amsterdam University Press. 
Rosenthal, G. (2017). Inside the United Nations: Multilateral Diplomacy Up Close. Routledge.

Sands QC, Philippe and Pierre Klein. (2009). Bowett's Law of International Institutions. Ed. 5, Cet. 10. London: Thomson Reuters (Legal) Limited.

Schwartzberg, J. E. (2016). Transforming the United Nations system: designs for a workable world. Brookings Institution Press.

Shaw QC, Malcolm N. (2008). International Law. Ed. 6. Cet. 1. Cambridge: Cambridge University Press.

Slomanson, William. (2011). Fundamental Perspectives on International Law.

Ed. 6. Boston: Wadsworth Cengage Learning.

Suwardi, Sri Setianingsih. (2004). Introduction to the Law of International Organizations. Jakarta: University of Indonesia.

Stokke, Olav. (2009). The UN and Development: from Aid to Cooperation. Bloomington: Indiana University Press.

United Nations Information Center. (2017). Basic Facts about the United Nations. Ed. 42. New York: United Nations, 2017.

Volger, H. (Ed.). (2009). A concise encyclopedia of the United Nations. Brill.

Weiss, T. G., \& Daws, S. (Eds.). (2018). The Oxford Handbook on the United Nations. Oxford University Press.

\section{Journal}

Baumann, M. O. (2018). Forever North-South? The political challenges of reforming the UN development system. Third World Quarterly, 39(4), 626-641.

Elie, J. (2010). The Historical Roots of Cooperation Between the UN High Commissioner for Refugees and the International Organization for Migration. Global Governance, 16, 345-360.

Igwe, I. O. History of the International Economy: The Bretton Woods System and its Impact on the Economic Development of Developing Countries. Journal of Law Athens, 4, 105-126.

James, H. (2012). The multiple contexts of Bretton Woods. Oxford Review of Economic Policy, 28(3), 411-430.

Missbach, Antje. (2017). "Troubled Transit: Asylum Seekers Stuck in Indonesia."Journal of Refugee Studies, 30, 628-630.

Nethery, A., Rafferty-Brown, B., \& Taylor, S. (2012). Exporting detention: Australia-funded immigration detention in Indonesia. Journal of Refugee Studies, 26(1), 88-109.

Sauvant, K. P. (2015). The negotiations of the United Nations code of conduct on transnational corporations: experience and lessons learned. the journal of world investment $\mathcal{E}$ trade, 16(1), 11-87.

Tan, N. F. (2016). The status of asylum seekers and refugees in Indonesia. International Journal of Refugee Law, 28(3), 365-383.

Van Genderen, Wanda Troszczynska. (2015). "Reforming the United Nations: State of Play, Ways Forward. "Directorate-General for External Policies Policy Department, 1-43.

Weiss, T. G. (2010). ECOSOC is dead, long live ECOSOC. Friedrich-EbertStiftung, Global Policy and Development. 1-17. 


\section{International Documents}

League of Nations. The Covenant of the League of Nations (1919).

United Nations. Charter of the United Nations (1945).

United Nations. New York Declaration on Refugees and Migrants. A / RES / $71 / 1$ (2016).

United Nations High Commissioner for Refugees. The Global Compact on Refugees (2018).

\section{Internet}

Cockburn, Harry. "US Only Country in the World to Vote against Work of the UN Refugee Agency." Retrieved from Https://www.independent.co.uk/news/world/americas/uspolitics/us-votes-against-un-refugee-agency -unhcr-resolution-trumpimmigration-asylum-mexico-border-a8633226.html.

Kleib, Hasan. "World Leadership Appreciation Indonesia in UNCTAD". Retrieved from https://mission-indonesia.org/2014/09/16/duniaapresiasi-kepemimpinan-indonesia-di-unctad.

United Nations Conference on Trade and Development. "Special High-Level Meeting of ECOSOC with UNCTAD, the World Bank, the IMF, and the WTO". Retrieved from https:// unctad.org/en/pages/MeetingDetails.aspx?meetingid=549.

United Nations Conference on Trade and Development. "UNCTAD Annual Report 2016". Retrieved from https://unctad.org/en/pages/PublicationWebflyer.aspx?publicationi $\underline{\mathrm{d}=1857}$.

United Nations High Commissioner for Refugees. "History of UNHCR". Retrieved from http://www.unhcr.org/history-of-unhcr.html.

United Nations High Commissioner for Refugees. "United Nations General Assembly". Retrieved from http://www.unhcr.org/united-nationsgeneral-assembly.html.

United Nations High Commissioner for Refugess. "What We Do". Retrieved from http://www.unhcr.org/what-we-do.html. 